\title{
Potassium uptake efficiency and dynamics in the rhizosphere of maize (Zea mays L.), wheat (Triticum aestivum L.), and sugar beet (Beta vulgaris L.) evaluated with a mechanistic model
}

\author{
Debasmita Samal • John L. Kovar • \\ Bernd Steingrobe $\cdot$ Upkar S. Sadana • \\ Pratapbhanu S. Bhadoria $\cdot$ Norbert Claassen
}

Received: 7 October 2009 /Accepted: 28 December 2009/Published online: 23 January 2010

(C) The Author(s) 2010. This article is published with open access at Springerlink.com

\begin{abstract}
Plant species differ in nutrient uptake efficiency. With a pot experiment, we evaluated potassium (K) uptake efficiency of maize (Zea mays L.), wheat (Triticum aestivum L.), and sugar beet (Beta vulgaris L.) grown on a low-K soil. Sugar beet and wheat maintained higher shoot $\mathrm{K}$ concentrations, indicating higher $\mathrm{K}$ uptake efficiency. Wheat acquired more $\mathrm{K}$ because of a greater root length to shoot dry weight ratio. Sugar beet accumulated more shoot $\mathrm{K}$ as a result of a 3- to 4-fold higher $\mathrm{K}$ influx as compared to wheat and maize, respectively. Nutrient uptake model NST 3.0 closely predicted $\mathrm{K}$ influx when $250 \mathrm{mg} \mathrm{K} \mathrm{kg}{ }^{-1}$ were added to the soil, but under-predicted $\mathrm{K}$ influx under low K supply. Sensitivity analysis showed that
\end{abstract}

Responsible Editor: Philippe Hinsinger.

D. Samal $\cdot$ B. Steingrobe $\cdot$ U. S. Sadana $\cdot$ N. Claassen Department of Crop Science, Plant Nutrition Section, Carl-Sprengel-Weg 1,

Göttingen 37075, Germany

J. L. Kovar

National Laboratory for Agriculture and the Environment, 2110 University Boulevard,

Ames, IA 50011-3120, USA

Present Address:

D. Samal $(\bowtie) \cdot$ P. S. Bhadoria

Agricultural and Food Engineering Department,

Indian Institute of Technology,

Kharagpur 721302, India

e-mail: samal.debasmita@googlemail.com increasing soil solution $\mathrm{K}$ concentration $\left(\mathrm{C}_{\mathrm{Li}}\right)$ by a factor of $1.6-3.5$ or buffer power (b) 10- to 50-fold resulted in $100 \%$ prediction of $\mathrm{K}$ influx. When both maximum influx $\left(\mathrm{I}_{\max }\right)$ and $\mathrm{b}$ were increased by a factor of 2.5 in maize and wheat and 25 in sugar beet, the model could predict measured K influx $100 \%$. In general, the parameter changes affected mostly calculated $\mathrm{K}$ influx of root hairs, demonstrating their possible important role in plant $\mathrm{K}$ efficiency.

Keywords Maize $\cdot$ Mechanistic model .

Potassium efficiency $\cdot$ Rhizosphere $\cdot$ Sugar beet $\cdot$ Wheat

\section{Introduction}

Potassium uptake efficiency determines the ability of plants to take up $\mathrm{K}$ under low soil $\mathrm{K}$ availability. Plant species and cultivars of a given species differ in their $\mathrm{K}$ uptake efficiency (Trehan and Claassen 1998; Dessougi et al. 2002; Trehan and Sharma 2002; Zhang et al. 2007). Trehan and Claassen (1998) reported that K uptake efficiency of potato (Solanum tuberosum L.) is less than that of wheat and sugar beet. Dessougi et al. (2002) studied the K efficiency of spring wheat (Triticum aestivum L.), spring barley (Hordeum vulgare L.) and sugar beet grown under controlled conditions on a K-fixing sandy clay loam soil and reported that at low $\mathrm{K}$ concentration $(5-20 \mu M)$ in soil solution, sugar beet had a 7 - to 20 -fold higher $\mathrm{K}$ influx 
( $\mathrm{K}$ uptake per $\mathrm{cm}$ of root per second) than wheat and barley, indicating that sugar beet was more efficient in acquiring low available soil $\mathrm{K}$. To understand the differences in $\mathrm{K}$ uptake efficiency of different crops, one must look for the underlying mechanisms. The size of the root system, the physiology of uptake and the ability of plants to increase $\mathrm{K}$ solubility in the rhizosphere by exudation of organic compounds are considered mechanisms of uptake efficiency (Steingrobe and Claassen 2000; Rengel and Damon 2008).

Plants take up K exclusively from the soil solution pool, which is in a dynamic equilibrium with the exchangeable and, to a lesser extent, the nonexchangeable pools. Exchangeable $\mathrm{K}$ can be rapidly released from exchange sites on the surfaces of clay minerals and organic matter to replenish K-depleted soil solution (Steingrobe and Claassen 2000). Springob and Richter (1998) reported that exudation of organic acids and/or protons is not necessary to make nonexchangeable $\mathrm{K}$ available to plant roots. They found that a decrease of $\mathrm{K}$ concentration in soil solution below $3.5 \mu \mathrm{M}$ initiated a release of interlayer $\mathrm{K}$ in a Luvisol. The minimum concentration at which uptake is possible $\left(\mathrm{C}_{\mathrm{Lmin}}\right)$ for most plant species is well below $3.5 \mu M$. The source and release processes of nonexchangeable $\mathrm{K}$ from the rhizosphere of maize were evaluated by Moritsuka et al. (2004). They reported that interlayer $\mathrm{K}$ in a 2:1 type phyllosilicate was the main source of non-exchangeable $\mathrm{K}$ for maize, and that $\mathrm{K}$ was released through cation $\left(\mathrm{Ca}^{2+}, \mathrm{Mg}^{2+}\right.$, and $\mathrm{Na}^{+}$accumulated in the rhizosphere) exchange of the $\mathrm{K}$, rather than mineral dissolution by protons. Schneider (1997) conducted soil $\mathrm{K}$ sorption and desorption experiments for $16 \mathrm{~h}$ at five initial $\mathrm{Ca}$ concentrations (from 0 to $10^{-1} \mathrm{M}$ ) and followed by the measurement of soil exchangeable $\mathrm{K}$ (ammonium acetate extraction) and reported that the release of $\mathrm{K}$ increased and fixation of $\mathrm{K}$ decreased when $\mathrm{Ca}$ concentration increased.

Several researchers have reported that plants have developed a number of highly specific mechanisms to acquire $\mathrm{K}$ from soil. These include an increased $\mathrm{I}_{\max }$ at low K supply (Meyer 1993), the expression of $\mathrm{K}^{+}$ transporters, and $\mathrm{K}^{+}$channels in root cells, especially root hair cells, to ensure an adequate supply of $\mathrm{K}$ under low K supply (Brüggemann et al. 1999; Ahn et al. 2004; Reintanz et al. 2002). Root hairs contribute to $\mathrm{K}$ uptake capacity by increasing both root surface area and the extent of the $\mathrm{K}$ depletion zone. Root hairs create a steeper diffusion gradient simply because they have a smaller diameter than roots (Jungk 2001). Hogh-Jensen and Pedersen (2003) reported a positive correlation between the capacity to take up $\mathrm{K}$ from a $\mathrm{K}$-deficient soil and root hair length for pea (Pisum sativum L.), red clover (Trifolium pretense L.), lucerne (Medicago sativa L.), barley (Hordeum vulgare L.), rye (Secale cereale L.), perennial ryegrass (Lolium perenne L.) and oilseed rape (Brassica napus L.).

From models that consider soil solution concentration as a main input parameter for simulating nutrient flux from soil to plant roots (Claassen 1990), the factors influencing soil solution concentration with decreasing distance from the root can be derived. Apart from buffer capacity for a specific ion, which is related to binding sites for an ion in soil, solubility of related salts and chemical equilibrium in soil solution, soil water content, transport distance and nutrient uptake capacity of the root are important. Transport distance depends on root length density and distribution. Nutrient uptake capacity of a certain unit of root length depends on root surface area and affinity of the transporters for the ion (Engels and Marschner 1993; Rodriguez-Navarro 2000).

Potassium uptake and supply level of the soil can be described by a mechanistic model (Claassen et al. 1986; Claassen and Steingrobe 1999). The model calculates the diffusive and convective transport of nutrients towards the root under consideration of sorption and desorption processes. The uptake rate into the root is calculated by Michaelis-Menten kinetics. Applying a nutrient uptake model to wheat plants (Claassen 1994), it was shown that where calculated transport and uptake agreed well with measured data, the high $\mathrm{K}$ uptake efficiency of wheat was mainly due to its large root system. Dessougi et al. (2002) found that sugar beet had fewer roots, but it could realize much higher influx than calculated by the model. Investigating the mechanisms enabling sugar beet to obtain a high $\mathrm{K}$ influx, Dessougi (2001) reported that at high root length density, the $\mathrm{K}$ concentration in soil solution was approximately six times $(94.2 \mu M \mathrm{~K})$ the concentration measured in soil without plants under low $\mathrm{K}$ supply conditions $(15 \mu M \mathrm{~K})$. It was not clear though, whether the increase in soil solution $\mathrm{K}$ concentration was due to chemical mobilization of $\mathrm{K}$ by sugar beet root exudates or to problems in measuring $\mathrm{K}$ in soil solution. Measured $\mathrm{K}^{+}$may not have actually been in solution, but held on fine soil particles dispersed in the soil solution. 
The objective of this study was to better understand the $\mathrm{K}$ uptake mechanisms of maize, wheat and sugar beet under low K supply with the help of the nutrient uptake model NST 3.0 (Claassen 1994). Soil and plant parameters, including the contribution of root hairs, were determined for the three different plant species grown on a silty clay loam soil of low $\mathrm{K}$ status at two $\mathrm{K}$ levels. Where calculated $\mathrm{K}$ influx differed from measured $\mathrm{K}$ influx, a sensitivity analysis was conducted by changing different soil and plant parameters influencing $\mathrm{K}$ uptake, alone or in combination. Our purpose was to determine whether uptake kinetics alone could explain the differences in measured and calculated influx under low K supply or chemical mobilization of $\mathrm{K}$ in the rhizosphere should be considered.

\section{Materials and methods}

A pot culture experiment was conducted to evaluate $\mathrm{K}$ uptake efficiency and $\mathrm{K}$ dynamics in the rhizosphere of maize (Zea mays L. cv. 8481IT), wheat (Triticum aestivum L. cv. Thasos), and sugar beet (Beta vulgaris L. cv. Monza) and to determine the soil and plant parameters for nutrient uptake model calculations. The experiment was conducted in a controlled-climate chamber located in the USDA-ARS National Laboratory for Agriculture and the Environment, Ames, Iowa, with a light/dark regime of $16 / 8 \mathrm{~h}$ at $25 / 18^{\circ} \mathrm{C}$, relative humidity of $60 / 75 \%$, and photosynthetic active radiation during the light period (PAR) of $41 \mathrm{Wm}^{-2}$. Taintor silty clay loam soil (fine, montmorillonitic, mesic Typic Argiaquolls) of low $\mathrm{K}$ status $(58 \mu \mathrm{MK})$ was collected from the surface layer $(0-15 \mathrm{~cm})$ at the edge of a production field in southeastern Iowa. Field-moist samples were sieved to 2-mm particle size. To determine the initial soil chemical properties, subsamples of soil were air dried and analyzed for extractable $\mathrm{P}$ (Bray-1), exchangeable $\mathrm{K}, \mathrm{Ca}$, and $\mathrm{Mg}, \mathrm{pH}$, and organic matter content by the methods outlined in Brown (1998). Initially, the soil contained $16 \mathrm{mg} \mathrm{kg}^{-1}$ extractable P, $49 \mathrm{mg} \mathrm{kg}^{-1}$ exchangeable K, $4401 \mathrm{mg} \mathrm{kg}^{-1}$ exchangeable $\mathrm{Ca}, 314 \mathrm{mg} \mathrm{kg}^{-1}$ exchangeable $\mathrm{Mg}$, and $36 \mathrm{~g} \mathrm{~kg}^{-1}$ organic matter. The soil $\mathrm{pH}$ in water was 7.8 , and the cation exchange capacity of the soil was

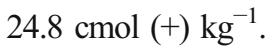

To begin the experiment, subsamples of soil were fertilized with 0 and $250 \mathrm{mg} \mathrm{K} \mathrm{kg}^{-1}$ soil as $\mathrm{KCl}$. A basal dose of $340 \mathrm{mg} \mathrm{N} \mathrm{kg}^{-1}$ soil as $\mathrm{NH}_{4} \mathrm{NO}_{3}$ was applied to all subsamples, and deionized water was added to bring the samples to field capacity moisture content ( $27 \%$ by weight). The treatments were then incubated for 1 week. The experiment was designed for two harvests. Plastic pots were filled with soil equivalent to $1.6 \mathrm{~kg}$ at oven-dryness for the first harvest and $3.0 \mathrm{~kg}$ for the second harvest. Before transplanting, seeds were pre-germinated in folded tissue paper placed vertically in a glass beaker containing aerated water in the controlled-climate chamber. The number of plants per pot was 6 and 3 for the first and second harvest, respectively. Each treatment was replicated three times. Three pots per treatment were left unplanted as controls for measurement of soil parameters and to determine the moisture loss through evaporation.

Maize plants were harvested 15 and 21 days after germination (DAG) for the first and second harvests, respectively. Wheat and sugar beet plants were harvested 19 and 26 DAG for the first and second harvests, respectively. At harvest, shoots were cut at the soil surface level and roots were carefully separated from the soil by gently shaking and sieving. Collected roots were washed repeatedly with distilled water by flooding over a sieve. To separate fine roots, a 550-g subsample of soil was placed in a hydro-pneumatic elutriation system (Smucker et al. 1982) that uses water, compressed air, and $530-\mu \mathrm{m}$ screens to wash soil from roots. Debris were removed manually, and roots were stored at $5^{\circ} \mathrm{C}$ in $20 \%(\mathrm{v} / \mathrm{v})$ ethanol in glass jars. After recording the fresh weight, shoot samples were dried at $60^{\circ} \mathrm{C}$ for $24 \mathrm{~h}$ and then at $105^{\circ} \mathrm{C}$ to a constant weight. Subsamples of ground shoot material were wet digested under pressure using concentrated $\mathrm{H}_{2} \mathrm{SO}_{4}$ and $30 \% \mathrm{H}_{2} \mathrm{O}_{2}$ (Mills and Jones 1996). Potassium concentration in the digests was measured by inductively coupled plasma (ICP) spectroscopy.

Root length and root surface area

To determine the length and surface area of harvested roots, samples were removed from storage jars and rinsed with deionized water to remove the ethanol. The roots were then stained dark blue by placing them for $5 \mathrm{~min}$ in a heated $\left(50^{\circ} \mathrm{C}\right)$ crystal violet solution made by adding $1 \mathrm{~g}$ of crystal violet stain to $100 \mathrm{~mL}$ of water. After staining, individual roots from each sample were arranged in water on glass trays and then scanned on a desktop scanner to obtain a digitized Tagged Image 
Format (TIF) image of the entire sample. These images were analyzed using the ROOTEDGE software (Kaspar and Ewing 1997). This program uses the edge chord algorithm (Ewing and Kaspar 1995) to estimate root perimeter and length. The total length and mean diameter for each sample were used to calculate the surface area of the roots.

Nutrient uptake model calculations — basis of the model

The NST 3.0 model of Claassen (1994), which accounts for nutrient uptake by both roots and root hairs, was used to simulate $\mathrm{K}$ uptake by the three plant species in this study. The model is based on three basic processes: (i) release of nutrients from the soil solid phase into the solution phase, which is governed by sorption and desorption processes, (ii) transport of nutrients to roots in the solution phase by mass flow and diffusion (Barber 1962), and (iii) nutrient uptake into the root, which depends on the nutrient concentration in the soil solution at the root surface and can be described by a modified Michaelis-Menten equation applied by Epstein and Hagen (1952) and later modified by Nielsen (1972). Root hairs are included in the model. Their radial distribution around the root is represented by the half distance among neighboring root hairs at different distances from the root cylinder. Their nutrient uptake is taken care of in the transport equation by a sink term which is calculated from the amount of root hairs and from the concentration of the nutrient at the distance from the root being considered. The influx into root hairs is concentration dependent following also a modified Michaelis-Menten kinetic with parameters specific for the root hairs.

The model output gives the concentration profiles around the root and a single root hair at different times of uptake, the nutrient influx for the root hairs and the root cylinder at different time intervals as well as the average nutrient influx for the whole growing root system and finally it gives the nutrient uptake of the whole root system for the period of calculation. For comparing measured and simulated or calculated values we used the $\mathrm{K}$ influx. The measured $\mathrm{K}$ influx is an average value for the whole growing root system (see Eq. 9). The simulated $\mathrm{K}$ influx was calculated in a similar manner and is therefore comparable with the measured value (for more details see Claassen et al. 1986). The model requires values of several soil and plant parameters for both roots and root hairs in order to calculate $\mathrm{K}$ uptake.

Soil parameters for model calculation

A second subsample of soil from each pot was used for determination of soil solution $\mathrm{K}$ and exchangeable $\mathrm{K}$ held on the solid phase of the soil. A column displacement method was used to determine initial soil solution $\mathrm{K}$ concentration $\left(\mathrm{C}_{\mathrm{Li}}\right)$. The method permits accurate determination of the unaltered composition of soil solution (Adams 1974). A sample of moist soil equivalent to $500 \mathrm{~g}$ at oven-dryness was packed into a Plexiglass column to a density of approximately $1.3 \mathrm{Mg} \mathrm{m}^{-3}$. Filter paper was placed on the top of each soil column to avoid evaporation losses during the collection. Deionized water was added to each column at a rate of $4 \mathrm{~mL} \mathrm{~h}^{-1}$ until the soils reached field capacity water content. The samples were allowed to equilibrate for $24 \mathrm{~h}$; then, $40 \mathrm{~mL}$ of de-ionized water were added at a rate of $4 \mathrm{~mL} \mathrm{~h}^{-1}$. The displaced solution was collected and filtered through a $0.20 \mu \mathrm{m}$ filter. The solutions were analyzed for $\mathrm{K}$ by atomic emission spectroscopy.

Soil solution concentration was measured for planted and unplanted pots at the time of each harvest. To calculate $\mathrm{K}$ influx for the period between the first and second pot harvests, an estimate of $\mathrm{C}_{\mathrm{Li}}$ in the larger pots at the time that the smaller pots were harvested was needed. Values for $\mathrm{C}_{\mathrm{Li}}$ in the larger (second harvest) pots were obtained from the relation between measured soil solution $\mathrm{K}$ concentration and the corresponding shoot $\mathrm{K}$ uptake for low $\left(0 \mathrm{mg} \mathrm{K} \mathrm{kg}^{-1}\right)$ and high $\left(250 \mathrm{mg} \mathrm{K} \mathrm{kg}^{-1}\right.$ soil) $\mathrm{K}$ treatments at both harvests (Fig. 1).

To determine solid phase $\mathrm{K}$, a 2-g subsample of soil from each pot was extracted with $1 \mathrm{M} \mathrm{NH}_{4} \mathrm{OAc}$ solution at pH 7 (Brown 1998). Potassium concentration in the extracts was determined via inductively coupled plasma (ICP) spectroscopy. Four other soil parameters necessary to calculate $\mathrm{K}$ uptake with the NST 3.0 model include:

$\mathrm{D}_{\mathrm{L}}$ Diffusion coefficient of $\mathrm{K}$ in water at $25^{\circ} \mathrm{C}, \mathrm{cm}^{2} \mathrm{~s}^{-1}$ (Parsons 1959)

$\theta \quad$ Volumetric water content is the volume of water per volume of soil, $\mathrm{cm}^{3} \mathrm{~cm}^{-3}$

f Impedance factor to account for the tortuous diffusion path of the ions through soil, calculated from $\mathrm{f}=0.970-0.17$ (Kaselowsky 1990); and 
b Buffer power calculated as the ratio of soil exchangeable $\mathrm{K}\left(\mathrm{mol} \mathrm{cm}^{-3}\right.$ soil) and the soil solution $\mathrm{K}$ concentration ( $\mathrm{mol} \mathrm{cm} \mathrm{cm}^{-3}$ soil solution).

Plant parameters for model calculation

\section{Mean root radius}

Mean root radius $\left(\mathrm{r}_{0}\right)$ was calculated from fresh root weight (FRW) in $g$ and root length (RL) in $\mathrm{cm}$, assuming a specific gravity for roots of $1 \mathrm{~g} \mathrm{~cm}^{-3}$ :

$r_{0}=\sqrt{\frac{F R W}{\pi \cdot R L}}$

\section{Average half distance between neighboring roots}

Average half distance between neighboring roots $\left(r_{1}\right)$ was calculated from the formula:

$r_{1}=\sqrt{\frac{\text { Soil volume }\left(\mathrm{cm}^{3}\right)}{\pi \cdot \text { Root length }(\mathrm{cm})}}$

\section{Water influx}

Assuming that young plants have exponential root growth, water influx $\left(v_{0}\right)$ was calculated from the formula:

$v_{0}=\frac{T_{2}-T_{1}}{R A_{2}-R A_{1}} \cdot \frac{\ln \left(R A_{2} / R A_{1}\right)}{t_{2}-t_{1}}$

where $\mathrm{T}_{2}-\mathrm{T}_{1}$ is the amount of water, $\mathrm{cm}^{3}$; transpired between $t_{1}$ and $t_{2}, s$; and RA is root surface area, $\mathrm{cm}^{2}$. Total evapo-transpiration loss of water was determined from the water loss from the pots with plants minus the water loss from the unplanted pots.

\section{Relative shoot growth rate}

Relative shoot growth rate (RGR) was calculated from the formula:

$R G R=\frac{\ln \left(S D W_{2} / S D W_{1}\right)}{t_{2}-t_{1}}$

where, SDW is shoot dry weight in $g$ and is the mean of three replications and $\mathrm{t}$ is time of harvest in seconds.

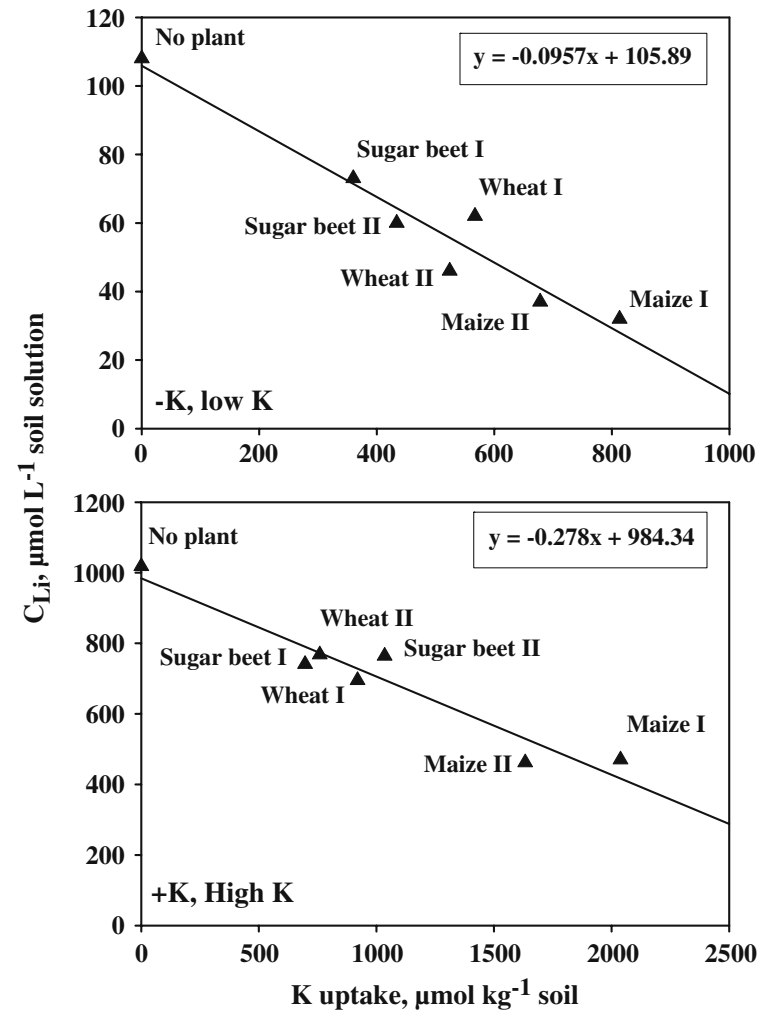

Fig. 1 Soil solution $K$ concentration $\left(\mathrm{C}_{\mathrm{Li}}\right)$ and corresponding $\mathrm{K}$ uptake of unplanted pots and of maize, wheat, and sugar beet grown on a low $\mathrm{K}$ soil with $(+\mathrm{K}$, high $\mathrm{K})$ and without $(-\mathrm{K}$, low $\mathrm{K}) \mathrm{K}$ fertilization after first (I) and second (II) plant harvests

\section{Relative root growth rate}

Relative root rate (k) was calculated from the formula:

$k=\frac{\ln \left(R L_{2} / R L_{1}\right)}{t_{2}-t_{1}}$

where, $\mathrm{RL}$ is root length in $\mathrm{cm}$ and $\mathrm{t}$ is time of harvest in days.

\section{Root hair distribution around the root}

To include the contribution of root hairs in the simulation of K uptake from soil, both physiological parameters describing the ability of root hairs to absorb $\mathrm{K}$ and morphological parameters, such as root hair radius and distribution around the root are needed. For this, the rhizosphere is divided into annular compartments. In each compartment, the root hair length is determined and knowing the volume of the compartment, an average half 
distance between neighboring root hairs $\left(\mathrm{r}_{1} \mathrm{~h}\right)$ is calculated. Because of both the cylindrical geometry and varying root hair length, the $r_{1}$ h values used in the model increase very rapidly with increasing distance from the root. The data for root hair distribution were taken from Hofbauer (1990), who conducted a similar experiment with comparable growth conditions.

\section{Plant parameters related to $K$ uptake kinetics}

The relationship between net $\mathrm{K}$ influx $\left(\mathrm{I}_{\mathrm{n}}\right)$ and $\mathrm{K}$ concentration at the root surface $\left(\mathrm{C}_{\mathrm{L} 0}\right)$ determines the $\mathrm{K}$ uptake kinetics. This relation can be described by a modified Michaelis-Menten function (Nielsen 1972):

$I_{n}=\frac{I_{\max }\left(C_{L 0}-C_{L \min }\right)}{K_{m}+C_{L 0}-C_{L \min }}$

where $\mathrm{I}_{\max }, \mathrm{K}_{\mathrm{m}}$ and $\mathrm{C}_{\mathrm{Lmin}}$ are as described below.

Maximum net influx $\left(\mathrm{I}_{\max }\right)$ was obtained from the influx measured from the treatment with the highest $\mathrm{K}$ level for each crop. This gives the maximum net $\mathrm{K}$ influx of plants well supplied with $\mathrm{K}$ for the growing conditions of our experiment. Plants of lower K supply may have a higher $\mathrm{I}_{\max }$, but to which extent this may be important will be studied through a sensitivity analysis on $\mathrm{I}_{\max }$. As the influx was calculated per $\mathrm{cm}$ of root, it was recalculated per $\mathrm{cm}^{2}$ of total root surface area including the surface area of root hairs per $\mathrm{cm}$ root. Root surface area (RSA) and root hair surface area (RHSA) were calculated from the formula:

$R S A=2 \pi r_{0} R L$

where $r_{0}$ is the root radius and RL is root length. In our case, total surface area was calculated for $1 \mathrm{~cm}$ of root, therefore RL was $1 \mathrm{~cm}$. For root hairs:

$R H S A=2 \pi r h_{0} R H L$

where $\mathrm{rh}_{0}$ is the root hair radius $[0.0005 \mathrm{~cm}$ as reported by Drew and Nye (1969) and Barber (1995)] and RHL is the total root hair length per $\mathrm{cm}$ of root. The RHL value was taken from Hofbauer (1990). Since $I_{\max }$ is extrapolated for infinite concentration, the measured value was increased by $10 \%$. The root surface area per $\mathrm{cm}$ root, including root hairs, is not exactly the same for the low $\mathrm{K}$ and high $\mathrm{K}$ treatments; therefore, the $\mathrm{I}_{\max }$ value is also different (Table 4).
Minimum solution concentration $\left(\mathrm{C}_{\mathrm{Lmin}}\right)$ is the concentration at which net influx equals zero. This value was taken from Meyer (1993).

The Michaelis constant $\left(\mathrm{K}_{\mathrm{m}}\right)$ is the difference between concentration at which influx is half of $\mathrm{I}_{\max }$ and $\mathrm{C}_{\mathrm{Lmin}}$. The values were taken from Meyer (1993).

\section{Net $K$ influx}

Potassium influx is the net amount of $\mathrm{K}$ taken up per unit root length (or root surface area) per unit time. Assuming that young plants have exponential root growth, the net $\mathrm{K}$ influx $\left(\mathrm{I}_{\mathrm{n}}\right)$ was calculated from the formula of Williams (1948):

$I_{n}=\frac{U_{2}-U_{1}}{R L_{2}-R L_{1}} \cdot \frac{\ln \left(R L_{2} / R L_{1}\right)}{t_{2}-t_{1}}$

where $\mathrm{U}$ is $\mathrm{K}$ content in $\mu \mathrm{mol}$ plant $^{-1}$; $\mathrm{RL}$ is root length per plant in $\mathrm{cm}$; $\mathrm{t}$ is time of harvest in seconds; and the subscripts 1 and 2 refer to the first and second harvest, respectively.

Statistical analysis

Plant growth, plant $\mathrm{K}$ uptake, and soil $\mathrm{K}$ treatment means were analyzed using two-way analysis of variance (ANOVA) with a balanced design (SigmaStat; Systat Software, Inc., Point Richmond, CA. USA). Where significant treatment differences were found, mean values were compared via Tukey's procedure.

\section{Results}

Plant growth and K uptake

Shoot dry weight (SDW), root length (RL), and K accumulation differed among the three species by the time of the second harvest (Table 1, Fig. 2). Maize attained the highest dry matter yield, which was twofold that of wheat and three-fold that of sugar beet. An application of $250 \mathrm{mg} \mathrm{kg}^{-1} \mathrm{~K}$ did not increase SDW of any of the species (Table 1), although K deficiency symptoms were observed in maize leaves under low K supply at 9 DAG. Potassium deficiency symptoms were not observed in wheat and sugar beet under low K supply by the time of the second harvest 
Table 1 Shoot dry weight (SDW), root length to shoot dry weight ratio (RL/SDW) and $\mathrm{K}$ uptake of maize, wheat and sugar beet grown on a low $\mathrm{K}$ soil with $(+\mathrm{K})$ and without $(-\mathrm{K}) \mathrm{K}$ fertilization at second harvest

\begin{tabular}{llllc}
\hline Crop species & K levels & $\begin{array}{l}\text { SDW } \\
\text { g plant }^{-1}\end{array}$ & $\begin{array}{l}\text { RL/SDW } \\
\mathrm{m} \mathrm{g}^{-1}\end{array}$ & $\begin{array}{l}\mathrm{K} \text { uptake } \\
\mu \text { mol Plant }\end{array}$ \\
\hline Maize & $-\mathrm{K}$ & $1.29 \mathrm{a} \mathrm{A}$ & $53 \mathrm{~b} \mathrm{~A}$ & $678 \mathrm{a} \mathrm{B}^{-1}$ \\
& $+\mathrm{K}$ & $1.42 \mathrm{a} \mathrm{A}$ & $67 \mathrm{~b} \mathrm{~A}$ & $1633 \mathrm{a} \mathrm{A}$ \\
Wheat & $-\mathrm{K}$ & $0.58 \mathrm{~b} \mathrm{~A}$ & $68 \mathrm{a} \mathrm{A}$ & $524 \mathrm{~b} \mathrm{~B}$ \\
& $+\mathrm{K}$ & $0.62 \mathrm{~b} \mathrm{~A}$ & $66 \mathrm{a} \mathrm{A}$ & $759 \mathrm{~b} \mathrm{~A}$ \\
Sugar beet & $-\mathrm{K}$ & $0.43 \mathrm{~b} \mathrm{~A}$ & $29 \mathrm{c} \mathrm{A}$ & $434 \mathrm{~b} \mathrm{~B}$ \\
& $+\mathrm{K}$ & $0.55 \mathrm{~b} \mathrm{~A}$ & $26 \mathrm{c} \mathrm{A}$ & $1035 \mathrm{~b} \mathrm{~A}$ \\
\hline
\end{tabular}

*Data are mean of 3 replicates. Lower case letters indicate significant difference of SDW, RL/SDW and $\mathrm{K}$ uptake among main effect of different crops at the same $\mathrm{K}$ level $(P \leq 0.001$, Tukey-test). Upper case letters indicate significant difference of SDW, RL/SDW and K uptake between different $\mathrm{K}$ levels for the same crop species $(P \leq 0.001$, Tukey-test $)$

at 26 DAG. Shoot $\mathrm{K}$ concentration in maize under low $\mathrm{K}$ supply was about half that of wheat and sugar beet at the second harvest (Fig. 2). Nevertheless, shoot $\mathrm{K}$ content, i.e., total $\mathrm{K}$ uptake, was significantly higher in maize as compared to wheat and sugar beet, which had similar shoot $\mathrm{K}$ contents (Table 1). Both shoot $\mathrm{K}$ concentration and total $\mathrm{K}$ uptake increased significantly in all the crops when grown under high
$\mathrm{K}$ supply, but the increase was greater in maize and sugar beet as compared to wheat (Table 1, Fig. 2).

Root length varied widely among the crop species, both under low and high K supply (Fig. 2). Under low $\mathrm{K}$ supply, root length of maize was 2- and 6-fold greater than that of wheat and sugar beet, respectively. An increase in soil $\mathrm{K}$ supply had little effect on root length of wheat and sugar beet, but significantly increased that of maize (Fig. 2). Root length to shoot dry weight ratio was also significantly higher in wheat as compared to maize and sugar beet under low $\mathrm{K}$ supply (Table 1).

During the growth period between first and second harvest, relative shoot growth rate of sugar beet was $23 \%$ higher than that of wheat and maize (Table 2). Shoot demand (SD) on the root is the $\mathrm{K}$ acquisition load imposed by shoot growth on each $\mathrm{cm}$ of root and is calculated by dividing the shoot growth rate by the average root length (RL), assuming that the roots of the plants grow exponentially:

$S D=\frac{S D W_{2}-S D W_{1}}{R L_{2}-R L_{1}} \cdot \frac{\ln \left(R L_{2} / R L_{1}\right)}{t_{2}-t_{1}}$

Under low K supply, shoot demand of sugar beet was 3 -fold greater than that of wheat and 2-fold greater than that of maize. The difference was more pronounced with high $\mathrm{K}$ supply (Table 2).
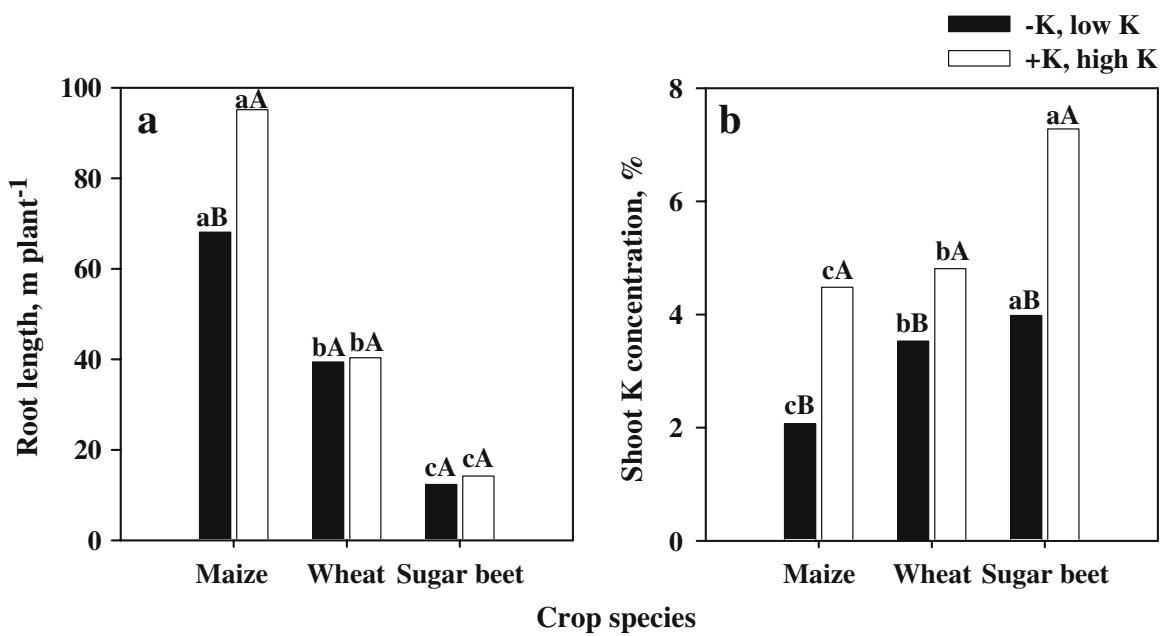

Fig. 2 Root length (a) and shoot $\mathrm{K}$ concentration (b) of maize, wheat, and sugar beet grown on a low K soil with (+K, high $\mathrm{K}$ ) and without (-K, low $\mathrm{K}) \mathrm{K}$ fertilization at second harvest. *Data are means of 3 replicates. Lower case letters indicate significant difference of root length and shoot $\mathrm{K}$ concentration among

main effect of different crops at the same $\mathrm{K}$ level $(P \leq 0.001$, Tukey-test). Upper case letters indicate significant difference of root length and shoot $\mathrm{K}$ concentration between different $\mathrm{K}$ levels for the same crop species $(P \leq 0.001$, Tukey-test) 
Table 2 Relative shoot growth rate and shoot demand on root of wheat, maize and sugar beet grown on a low $\mathrm{K}$ soil with $(+\mathrm{K})$ and without $(-\mathrm{K}) \mathrm{K}$ fertilization

\begin{tabular}{llll}
\hline Crops & K levels & $\begin{array}{l}\text { Relative shoot } \\
\text { growth rate } \\
10^{-6} \mathrm{~s}^{-1}\end{array}$ & $\begin{array}{l}\text { Shoot demand } \\
\text { on root } \\
10^{-10} \mathrm{~g} \mathrm{~s}^{-1} \mathrm{~cm}^{-1}\end{array}$ \\
\hline Maize & $-\mathrm{K}$ & $2.25 \mathrm{~b} \mathrm{~A}$ & $3.84 \mathrm{~b} \mathrm{~A}$ \\
& $+\mathrm{K}$ & $2.22 \mathrm{~b} \mathrm{~A}$ & $3.46 \mathrm{~b} \mathrm{~A}$ \\
Wheat & $-\mathrm{K}$ & $2.24 \mathrm{~b} \mathrm{~A}$ & $3.00 \mathrm{~b} \mathrm{~A}$ \\
& $+\mathrm{K}$ & $1.89 \mathrm{~b} \mathrm{~A}$ & $2.64 \mathrm{~b} \mathrm{~A}$ \\
Sugar beet & $-\mathrm{K}$ & $2.76 \mathrm{a} \mathrm{A}$ & $8.66 \mathrm{a} \mathrm{A}$ \\
& $+\mathrm{K}$ & $2.86 \mathrm{a} \mathrm{A}$ & $10.2 \mathrm{a} \mathrm{A}$ \\
\hline
\end{tabular}

*Data are means of 3 replicates. Lower case letters indicate significant difference of shoot growth rate and shoot demand among main effect of different crops at the same $\mathrm{K}$ level $(P \leq 0.05$, Tukey-test). Upper case letters indicate significant difference of Shoot growth rate and shoot demand between different $\mathrm{K}$ levels for the same crop species $(P \leq 0.05$, Tukey-test $)$

\section{Changes in soil $\mathrm{K}$ supply characteristics}

Soil solution $\mathrm{K}$ concentration in the mixture of rhizosphere and bulk soil of maize, wheat and sugar beet was measured after plant harvest. Soil solution K concentration was lower in the soil of all planted pots as compared to unplanted pots after both harvests (Table 3). The decrease, however, varied among the species. Under low K supply, solution K was 1.6-fold and 1.3-fold higher in soil in which sugar beet was grown than in soil in which maize and wheat, respectively, were grown. This difference in soil solution $\mathrm{K}$ concentrations reflected differences in $\mathrm{K}$ uptake among the crops, with uptake of $\mathrm{K}$ per pot by sugar beet being 1.6-fold and 1.2-fold lower than that of maize and wheat, respectively. As expected, there was a significant increase in soil solution $\mathrm{K}$ concentration in both planted and unplanted pots when $\mathrm{K}$ fertilizer was applied to the soil (Table 3).

Exchangeable $\mathrm{K}$ concentration of the soil was also measured in the mixture of rhizosphere and bulk soil collected after both harvests of the three species, as well as from unplanted control pots (Table 3). Values were used to calculate $\mathrm{K}$ buffer power for each of the treatment combinations. After the second harvest, $\mathrm{K}$ uptake by wheat and sugar beet had little effect on exchangeable $\mathrm{K}$ in the soil. However, uptake of $\mathrm{K}$ by maize significantly decreased exchangeable $\mathrm{K}$ as compared to unplanted pots (Table 3). To determine whether the change in exchangeable $\mathrm{K}$ after plant growth reflected plant $\mathrm{K}$ uptake, both parameters were compared (Fig. 3). All the values for low $\mathrm{K}$ soil after the first and second harvests were above the $1: 1$ symmetry line. This result indicates that about $50 \%$ of the $\mathrm{K}$ accumulated by the plants was from non-exchangeable forms.

Table 3 Soil solution K concentration and exchangeable K of the soil (mixture of rhizosphere and bulk soil) after harvest of maize, wheat, and sugar beet grown on a low $\mathrm{K}$ soil with $(+\mathrm{K})$ and without $(-\mathrm{K}) \mathrm{K}$ fertilization. Controls were unplanted pots

\begin{tabular}{|c|c|c|c|c|c|}
\hline \multirow[t]{3}{*}{ Harvest } & \multirow[t]{3}{*}{ Crops } & \multicolumn{2}{|c|}{ Soil solution $\mathrm{K}$} & \multicolumn{2}{|c|}{ Exchangeable $\mathrm{K}$} \\
\hline & & \multicolumn{2}{|l|}{$\mu \mathrm{mol} \mathrm{L}{ }^{-1}$} & \multicolumn{2}{|c|}{$\mu \mathrm{mol} \mathrm{kg}{ }^{-1}$ soil } \\
\hline & & $-\mathrm{K}$ & $+\mathrm{K}$ & $-\mathrm{K}$ & $+\mathrm{K}$ \\
\hline \multirow[t]{4}{*}{ First } & Maize & 32 c A & 470 c B & 949 с A & 3043 c B \\
\hline & Wheat & $62 \mathrm{~b} \mathrm{~A}$ & 695 b B & 1068 b A & 3889 b B \\
\hline & Sugar beet & $74 \mathrm{~b} \mathrm{~A}$ & $741 \mathrm{~b} \mathrm{~B}$ & $1111 \mathrm{~b} \mathrm{~A}$ & 3889 b B \\
\hline & Control & 109 a A & 1030 a $\mathrm{B}$ & 1256 a A & 4538 a B \\
\hline \multirow[t]{4}{*}{ Second } & Maize & $37 \mathrm{c} \mathrm{A}$ & 462 c B & 863 b A & 3299 b B \\
\hline & Wheat & $46 \mathrm{~b} \mathrm{~A}$ & 768 b B & 1026 a A & 4111 a B \\
\hline & Sugar beet & $60 \mathrm{~b} \mathrm{~A}$ & 764 b B & 1103 a A & 3940 a B \\
\hline & Control & 105 a A & 994 a B & 1231 a $\mathrm{A}$ & 4154 a B \\
\hline
\end{tabular}

* Data are means of 3 replicates. Lower case letters indicate significant difference of soil solution $\mathrm{K}$ or exchangeable $\mathrm{K}$ among main effect of different crops at the same $\mathrm{K}$ level $(P \leq 0.001$, Tukey-test). Upper case letters indicate significant difference of soil solution $\mathrm{K}$ or exchangeable $\mathrm{K}$ between different $\mathrm{K}$ levels for the same crop species $(P \leq 0.001$, Tukey-test) 


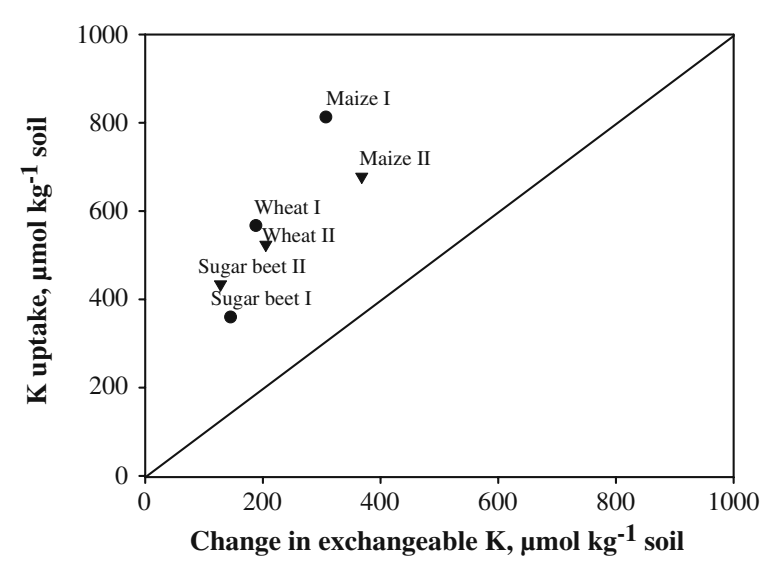

Fig. 3 Potassium uptake and corresponding change in exchangeable $\mathrm{K}$ in soil (average of bulk and rhizosphere soil) of maize, wheat, and sugar beet grown on a low $\mathrm{K}$ soil without $\mathrm{K}$ fertilizer $(-\mathrm{K})$ at first and second harvest

\section{Simulation of K uptake by the NST 3.0 model}

The measured soil, root, and root hair parameters (Tables 4 and 5) were used in the NST 3.0 nutrient uptake model to calculate $\mathrm{K}$ influx by maize, wheat, and sugar beet. Measured and calculated influx by the three species are summarized in Table 6 . In the low-K treatment, measured $\mathrm{K}$ influx was $8.45 \times 10^{-7} \mu \mathrm{mol} \mathrm{cm} \mathrm{cm}^{-1}$ $\mathrm{s}^{-1}$ for sugar beet, which was 4-fold higher than that of maize and 3-fold higher than that of wheat. With increasing $\mathrm{K}$ supply, measured $\mathrm{K}$ influx of maize and sugar beet doubled, while that of wheat increased 1.2 times. Under high $\mathrm{K}$ supply, $\mathrm{K}$ influx of sugar beet was 5- and 6-fold higher than that of maize and wheat, respectively. Hence, sugar beet had a higher $\mathrm{K}$ influx than wheat and maize under both low and high $\mathrm{K}$ supply.

In order to explain the differences in $\mathrm{K}$ influx among the crops, we included root hairs in the model calculations. Results in Fig. 4 show the calculated depletion of $\mathrm{K}$ from the rhizosphere of the three crop species at both low and high $\mathrm{K}$ supply. According to the model calculations, sugar beet decreased solution $\mathrm{K}$ concentration at the root surface to $3 \times 10^{-3} \mu \mathrm{mol} \mathrm{cm} \mathrm{cm}^{-3}$ as compared to $7.6 \times$ $10^{-3} \mu \mathrm{mol} \mathrm{cm}{ }^{-3}$ for wheat and $9.9 \times 10^{-3} \mu \mathrm{mol} \mathrm{cm} \mathrm{cm}^{-3}$ for maize after 7 days of uptake at low $\mathrm{K}$ supply (6 days of uptake for maize). Under high $\mathrm{K}$ supply $\left(\mathrm{C}_{\mathrm{Li}}\right.$ of $\left.933 \times 10^{-3} \mu \mathrm{mol} \mathrm{K} \mathrm{cm}^{-3}\right)$, sugar beet decreased $\mathrm{K}$ concentration at the root surface to $110 \times$ $10^{-3} \mu \mathrm{mol} \mathrm{cm}{ }^{-3}$, whereas wheat decreased it to $608 \times$ $10^{-3} \mu \mathrm{mol} \mathrm{cm}{ }^{-3}$ and maize to $320 \times 10^{-3} \mu \mathrm{mol} \mathrm{cm} \mathrm{cm}^{-3}$. These results suggest that the higher $\mathrm{K}$ influx of sugar beet was due to its capability to decrease solution $\mathrm{K}$ concentration at the root surface to a relatively lower value, thereby increasing the con-
Table 4 Plant and soil parameters used for the NST 3.0 nutrient uptake model calculations. Values are for maize, wheat, and sugar beet grown on a low $\mathrm{K}$ soil with $\left(250 \mathrm{mg} \mathrm{kg}^{-1}\right)$ and without $\left(0 \mathrm{mg} \mathrm{kg}^{-1}\right) \mathrm{K}$ fertilization

\begin{tabular}{|c|c|c|c|c|c|c|}
\hline \multirow[t]{3}{*}{ Parameters } & \multicolumn{6}{|c|}{$\mathrm{K}$ applied, $\mathrm{mg} \mathrm{kg}^{-1}$ soil } \\
\hline & 0 & 250 & 0 & 250 & 0 & 250 \\
\hline & Maize & & Wheat & & Sugar beet & \\
\hline \multicolumn{7}{|l|}{ Plant parameters } \\
\hline $\mathrm{I}_{\max }, 10^{-6} \mu \mathrm{mol} \mathrm{cm} \mathrm{cs}^{-2}$ & 5.02 & 4.00 & 3.73 & 3.55 & 21.6 & 22.5 \\
\hline $\mathrm{K}_{\mathrm{m}}, 10^{-2} \mu \mathrm{mol} \mathrm{cm}-3$ & 3.2 & 3.2 & 1.0 & 1.0 & 1.2 & 1.2 \\
\hline $\mathrm{C}_{\mathrm{Lmin}}, 10^{-3} \mu \mathrm{mol} \mathrm{cm}{ }^{-3}$ & 2.0 & 2.0 & 2.0 & 2.0 & 2.0 & 2.0 \\
\hline $\mathrm{r}_{0}, 10^{-2} \mathrm{~cm}$ & 1.01 & 1.13 & 1.05 & 1.08 & 1.05 & 0.96 \\
\hline $\mathrm{v}_{0}, 10^{-7} \mathrm{~cm}^{3} \mathrm{~cm}^{-2} \mathrm{~s}^{-1}$ & 4.33 & 6.30 & 38.05 & 34.40 & 95.38 & 120.04 \\
\hline $\mathrm{r}_{1}, 10^{-2} \mathrm{~cm}$ & 18.8 & 18.7 & 27.2 & 24.4 & 56.6 & 55.9 \\
\hline $\mathrm{k}, \mathrm{d}^{-1}$ & 0.1517 & 0.2086 & 0.1584 & 0.1321 & 0.2008 & 0.2169 \\
\hline $\mathrm{RL}_{0}, \mathrm{~cm}$ & 2703 & 2719 & 1298 & 1601 & 299 & 306 \\
\hline \multicolumn{7}{|l|}{ Soil parameters } \\
\hline $\mathrm{C}_{\mathrm{Li}}, \mu \mathrm{mol} \mathrm{cm}{ }^{-3}$ & 0.085 & 0.833 & 0.092 & 0.916 & 0.097 & 0.933 \\
\hline$\theta, \mathrm{cm}^{3} \mathrm{~cm}^{-3}$ & 0.30 & 0.30 & 0.30 & 0.30 & 0.30 & 0.30 \\
\hline $\mathrm{f}$ & 0.12 & 0.12 & 0.12 & 0.12 & 0.12 & 0.12 \\
\hline $\mathrm{D}_{\mathrm{L}}, 10^{-5} \mathrm{~cm}^{2} \mathrm{~s}^{-1}$ & 1.98 & 1.98 & 1.98 & 1.98 & 1.98 & 1.98 \\
\hline $\mathrm{b}$ & 16.1 & 6.2 & 16.1 & 6.2 & 16.1 & 6.2 \\
\hline
\end{tabular}


Table 5 Root hair number, length, surface area (assuming a root hair radius of $0.0005 \mathrm{~cm}$ ), and length density distribution in annular compartments around the root, characterized by the mean half distance $\left(\mathrm{r}_{1} \mathrm{~h}\right)$ between root hairs. Values are estimates for maize, wheat, and sugar beet grown on a low $\mathrm{K}$ soil with (250 mg kg-1) and without $\left(0 \mathrm{mg} \mathrm{kg}{ }^{-1}\right) \mathrm{K}$ fertilization (Hofbauer 1990)

\begin{tabular}{|c|c|c|c|c|c|c|}
\hline \multirow[t]{4}{*}{ Compartment distance from root, $\mathrm{cm}$} & \multicolumn{6}{|c|}{$\mathrm{K}$ applied, $\mathrm{mg} \mathrm{kg}^{-1}$} \\
\hline & 0 & 250 & 0 & 250 & 0 & 250 \\
\hline & \multicolumn{2}{|l|}{ Maize } & \multicolumn{2}{|l|}{ Wheat } & \multicolumn{2}{|c|}{ Sugar beet } \\
\hline & \multicolumn{6}{|c|}{$\mathrm{r}_{1} \mathrm{~h}, 10^{-3} \mathrm{~cm}$} \\
\hline $0.00-0.02$ & 12 & 10 & 11 & 11 & 10 & 9 \\
\hline $0.02-0.03$ & 47 & 26 & 26 & 27 & 30 & 36 \\
\hline $0.04-0.06$ & 159 & 82 & 73 & 54 & 85 & 145 \\
\hline $0.06-0.08$ & 386 & 254 & 241 & 104 & 140 & 422 \\
\hline $0.08-0.10$ & 963 & - & 925 & 207 & 202 & - \\
\hline $0.10-0.12$ & - & - & - & 985 & 336 & - \\
\hline $0.12-0.14$ & - & - & - & - & 663 & - \\
\hline \multicolumn{7}{|l|}{ Root hair parameters } \\
\hline $\mathrm{RH}$ length, $\mathrm{cm} \mathrm{cm}^{-1}$ root & 7.8 & 9.4 & 8.9 & 9.5 & 8.0 & 9.0 \\
\hline RH number, $\mathrm{cm}^{-1}$ root & 355 & 476 & 338 & 352 & 440 & 599 \\
\hline Average length of $\mathrm{RH}, \mathrm{cm}$ & 0.022 & 0.020 & 0.026 & 0.027 & 0.017 & 0.015 \\
\hline $\mathrm{RH}$ surface area, $\mathrm{cm}^{2} \mathrm{~cm}^{-2}$ root & 0.39 & 0.42 & 0.42 & 0.44 & 0.38 & 0.47 \\
\hline
\end{tabular}

centration gradient and consequently, the diffusive transport of $\mathrm{K}$ to the root surface.

Comparing calculated and measured values, there was a close prediction of $\mathrm{K}$ influx under high $\mathrm{K}$ supply for wheat and maize, but a slight underprediction for sugar beet. Under low K supply, there was underprediction of $\mathrm{K}$ influx for all crops. However, prediction was poorest for sugar beet, being only $31 \%$ of the measured influx, while that of wheat and maize was $68 \%$ and $64 \%$, respectively (Table 6). This suggests that either the input parameters were incorrectly estimated or that some other processes played a role, but were not considered in the principles underlying the model.
Sensitivity analysis

To find the reason for under prediction of $\mathrm{K}$ influx, a sensitivity analysis was conducted by incrementally changing the values of initial solution $\mathrm{K}$ concentration $\left(\mathrm{C}_{\mathrm{Li}}\right)$, maximum $\mathrm{K}$ influx $\left(\mathrm{I}_{\max }\right)$, buffer power $(\mathrm{b})$, and a combination of $I_{\max }$ and $b$. The parameters $I_{\max }$ and $\mathrm{b}$ are difficult to accurately determine. There are several ways to estimate $I_{\max }$ for plants and $b$ for soils. Maximum uptake capacity is sometimes determined from solution culture experiments, where growing conditions are quite different from soil. Thus, a sensitivity analysis for these parameters is justified.
Table 6 Measured and calculated root $\mathrm{K}$ influx of maize, wheat, and sugar beet grown on a low $\mathrm{K}$ soil with $(+\mathrm{K})$ and without $(-\mathrm{K})$ $\mathrm{K}$ fertilization

\begin{tabular}{|c|c|c|c|c|}
\hline \multirow[t]{3}{*}{ Crops } & \multirow[t]{3}{*}{ K levels } & \multicolumn{3}{|l|}{$\mathrm{K}$ influx } \\
\hline & & \multicolumn{3}{|c|}{$10^{-7} \mu \mathrm{mol} \mathrm{cm} \mathrm{s}^{-1} \mathrm{~s}^{-1}$} \\
\hline & & Calculated & Measured & Calculated / Measured \\
\hline \multirow[t]{2}{*}{ Maize } & $-\mathrm{K}$ & 1.27 & 1.99 & 0.64 \\
\hline & $+\mathrm{K}$ & 4.33 & 3.87 & 1.12 \\
\hline \multirow[t]{2}{*}{ Wheat } & $-\mathrm{K}$ & 1.77 & 2.59 & 0.68 \\
\hline & $+\mathrm{K}$ & 3.90 & 3.22 & 1.21 \\
\hline \multirow[t]{2}{*}{ Sugar beet } & $-K$ & 2.64 & 8.45 & 0.31 \\
\hline & $+\mathrm{K}$ & 15.10 & 19.00 & 0.80 \\
\hline
\end{tabular}


Fig. 4 Changes in calculated solution $\mathrm{K}$ concentration profiles with time in the rhizosphere of maize, wheat, and sugar beet grown on a low $\mathrm{K}$ soil with $(+\mathrm{K})$ and without $(-\mathrm{K}) \mathrm{K}$ fertilization. Horizontal lines indicate initial soil solution concentration $\left(\mathrm{C}_{\mathrm{Li}}\right)$
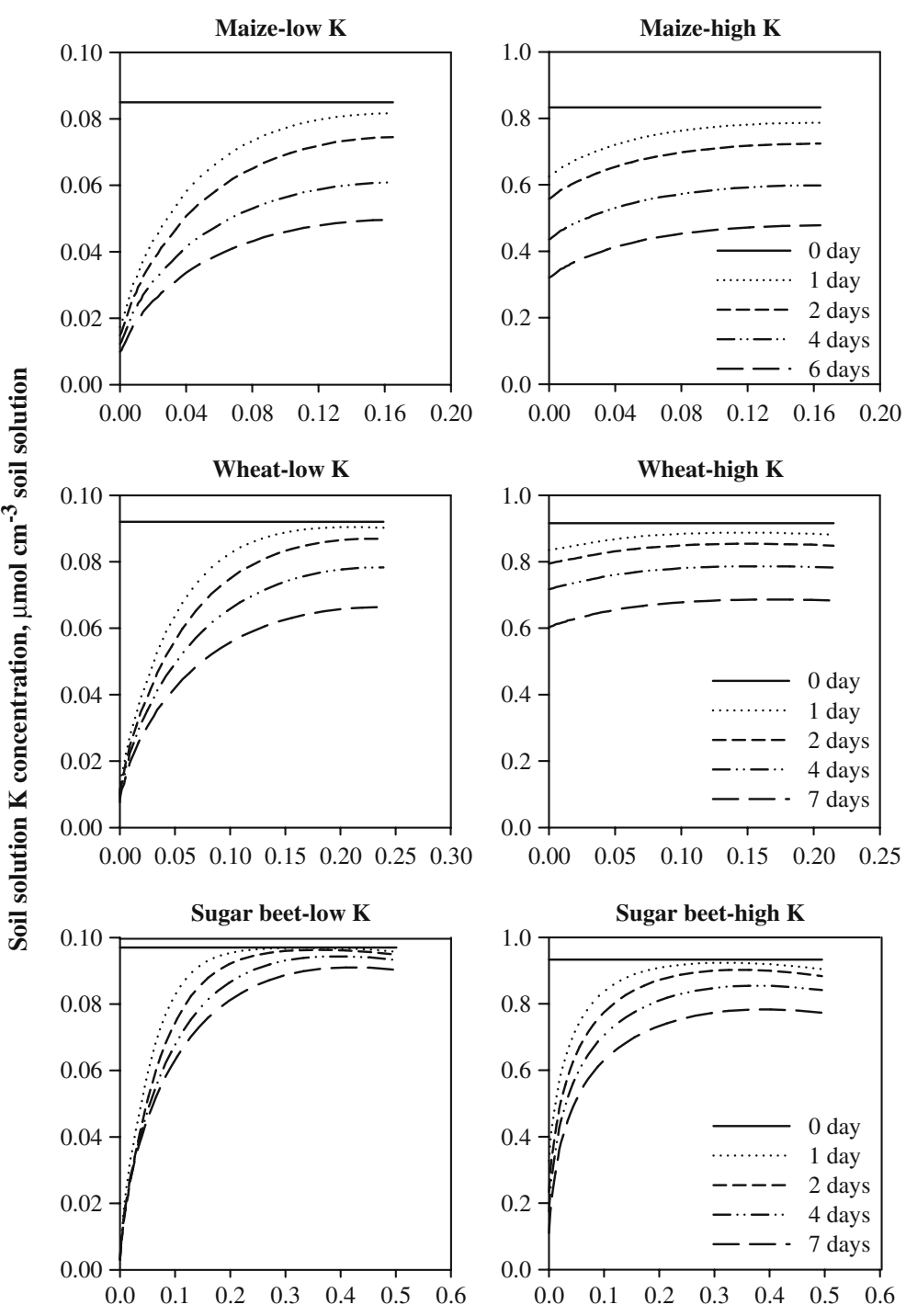

Distance from root surface, $\mathrm{cm}$
The sensitivity analysis for $\mathrm{C}_{\mathrm{Li}}$ showed that by increasing the value by a factor of 1.6 , we could get $100 \%$ prediction of measured $\mathrm{K}$ influx in wheat and maize (Fig. 5). For sugar beet, the same was achieved by increasing $\mathrm{C}_{\mathrm{Li}}$ by a factor of 3.5 .

An increase in the buffer power by a factor of 10 resulted in $100 \%$ prediction by the model for wheat and maize (Fig. 6a). For sugar beet, however, agreement was achieved by increasing the buffer power 50 times. Model calculations also indicated that in maize and wheat, the root cylinder absorbed most of the $\mathrm{K}$, whereas in sugar beet, root hairs absorbed up to twice as much as the root cylinder.
An increase in the $I_{\max }$ value increased calculated $\mathrm{K}$ influx for all the three crop species (Fig. 6b). However, even after increasing $\mathrm{I}_{\max } 25$-fold, the model prediction for $\mathrm{K}$ influx was $0.33,0.53$ and 0.83 of the measured $\mathrm{K}$ influx for sugar beet, wheat and maize, respectively. It is interesting to note that the effect of $I_{\max }$ in increasing calculated $\mathrm{K}$ influx was only due to the effect of root hairs; increasing $\mathrm{I}_{\max }$ had little effect on $\mathrm{K}$ influx of the root cylinder. For sugar beet, the contribution of root hairs to $\mathrm{K}$ influx was higher than that of the root cylinder for all levels of the $I_{\max }$ change ratio. For wheat and maize, the contribution of root hairs to $\mathrm{K}$ influx was lower 
$\rightarrow$ Calulated influx at different $\mathrm{C}_{\mathrm{Li}}$ change ratio Measured influx
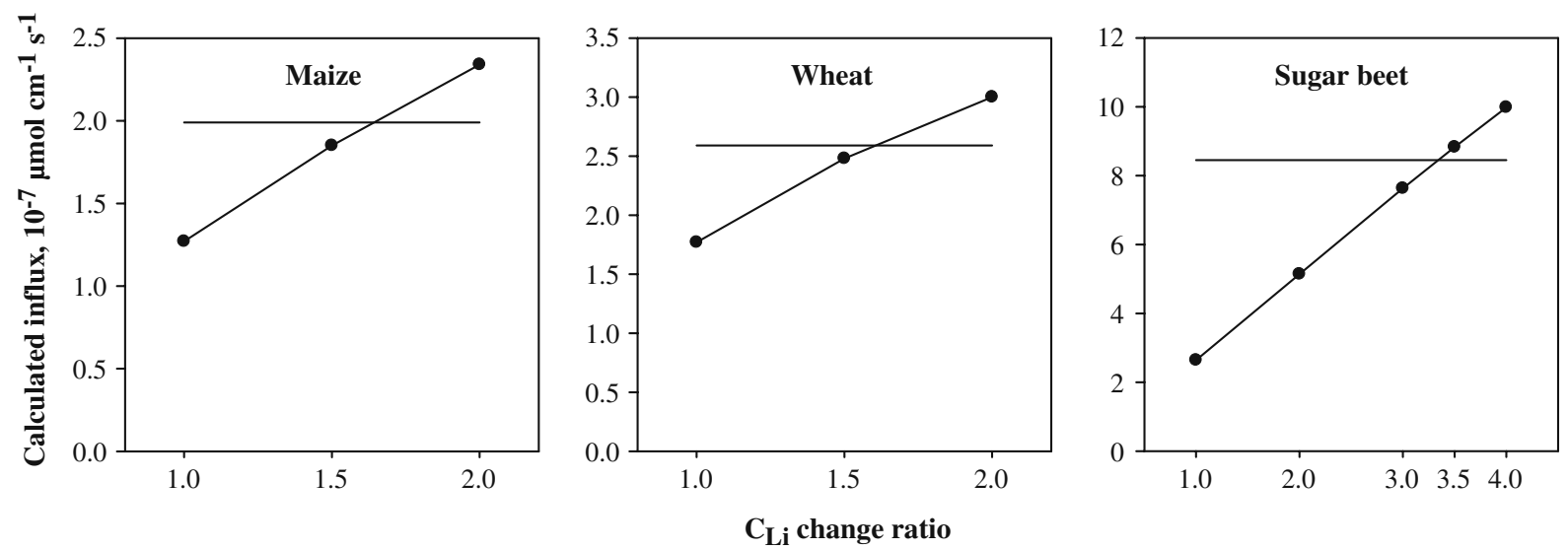

Fig. 5 Sensitivity of calculated influx to changing the initial soil solution concentration $\left(\mathrm{C}_{\mathrm{Li}}\right)$ by a factor given by change ratio. Measured influx of unchanged $\mathrm{C}_{\mathrm{Li}}$ is given by the horizontal line

than that of root cylinder, but increasing $I_{\max }$ gradually increased root hair $\mathrm{K}$ influx.

To determine why an increase in the $I_{\max }$ value increased root hair $\mathrm{K}$ influx, but not root cylinder influx, we calculated $\mathrm{K}$ influx for wheat without including root hairs, but using the mean root radius and the mean radius of the root hairs $(0.0005 \mathrm{~cm})$. With these separate calculations, we were able to examine the concentration profile around the root and the root hair (Fig. 7). From these profiles, it can be seen that increasing $\mathrm{I}_{\max }$ of the root cylinder 10-fold did not affect the concentration profile or the calculated $\mathrm{K}$ influx. In case of the root hairs, however, increasing $I_{\max }$ by a factor of 10 resulted in a 6-fold increase in calculated $\mathrm{K}$ influx. The reason for this can be derived from the concentration profiles. At the root surface, the soil solution $\mathrm{K}$ concentration was already very low $\left(10 \times 10^{-3} \mu \mathrm{mol} \mathrm{cm}{ }^{-3}\right)$ with the original $\mathrm{I}_{\max }$ (control), so by increasing $\mathrm{I}_{\max }$ to a higher value, there was little opportunity to further decrease the $\mathrm{K}$ concentration at the root cylinder surface. In this case, soil transport was limiting $\mathrm{K}$ uptake. In contrast, $\mathrm{K}$ concentration at the root hair surface of the control was much higher $(80 \times$ $10^{-3} \mu \mathrm{mol} \mathrm{cm} \mathrm{cm}^{-3}$ ), so that root hairs were able to decrease the concentration further, thereby creating a steeper concentration gradient to allow higher diffusive transport of $\mathrm{K}$ towards the root, which resulted in a 6fold increase in $\mathrm{K}$ influx. An alternative explanation of the fact that root hairs take up more $\mathrm{K}$ than root by increasing $\mathrm{I}_{\max }$ could be that root hairs deplete the soil around the root more. Therefore, the soil around the root is already depleted by the root hairs and thus no additional $\mathrm{K}$ can be taken up by the root itself.

A sensitivity analysis conducted with a single parameter could be insufficient, because several parameters are often interrelated (Claassen and Steingrobe 1999). Consequently, a sensitivity analysis was done by increasing $\mathrm{I}_{\max }$ and $\mathrm{b}$ at the same time, and by doing so, there was a closer prediction of $\mathrm{K}$ influx. These two parameters were changed simultaneously because in case of root hairs there is strong competition and even complete depletion of the available $\mathrm{K}$ pool among them. So, changing only $\mathrm{I}_{\max }$, the available $\mathrm{K}$ pool may be limiting $\mathrm{K}$ uptake. Changing only $\mathrm{b}$ (and thereby the available $\mathrm{K}$ pool at constant $\mathrm{C}_{\mathrm{Li}}$ ) the uptake capacity of the root hairs may become the limiting factor. Therefore changing both parameters these limitations may be overcome. By increasing both parameters by a factor of 2.5 , there was $100 \%$ agreement between predicted and measured $\mathrm{K}$ influx in wheat and maize (Fig. 6c). For sugar beet, however, $100 \%$ agreement was achieved by increasing both parameters by a factor of 25 . In contrast, increasing $\mathrm{I}_{\max }$ alone by a factor of 25

Fig. 6 a Sensitivity of calculated $\mathrm{K}$ influx of the root cylinder, root hairs, and the sum of both to changing the buffer power (b) given by the change ratio. b Sensitivity of calculated $\mathrm{K}$ influx of the root cylinder, root hairs, and the sum of both (total root influx) to changing the maximum influx rate $\left(I_{\max }\right)$ given by the change ratio. c Sensitivity of calculated $K$ influx to changing both $\mathrm{I}_{\max }$ and $\mathrm{b}$ by a factor given by change ratio 
a

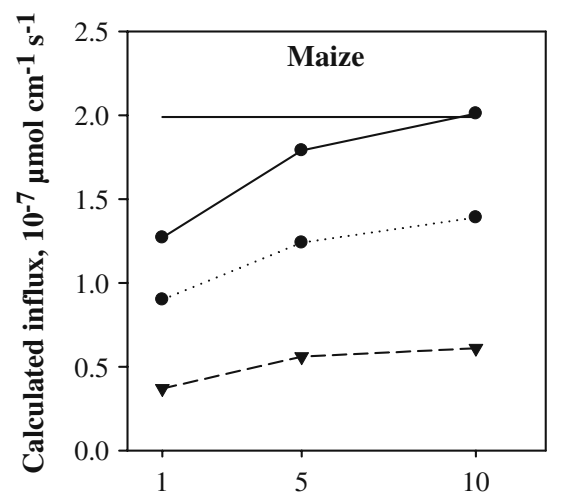

b

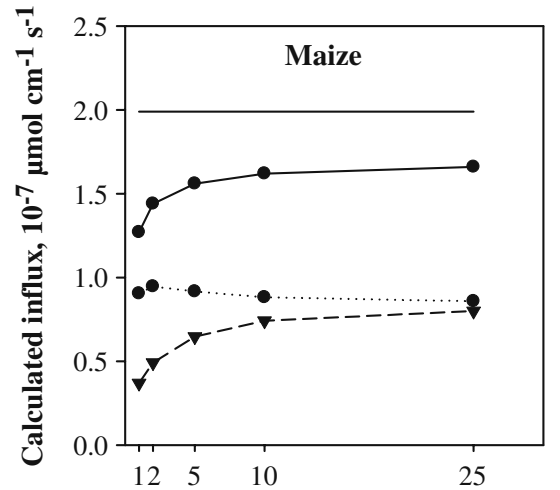

C

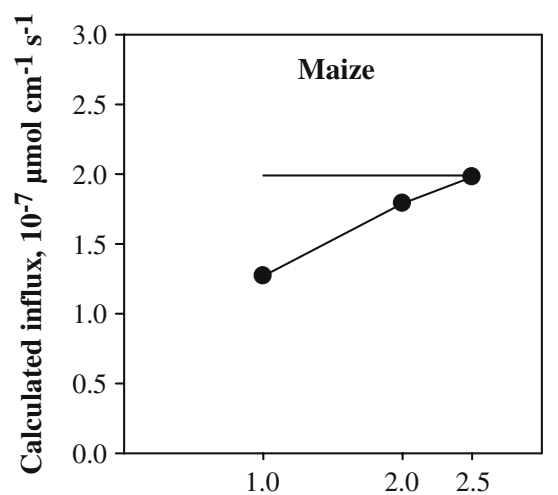

Calculated influx of total root at different $b$ change ratio Calculated influx of root cylinder at different $b$ change ratio Calculated influx of root hairs at different $b$ change ratio Measured influx
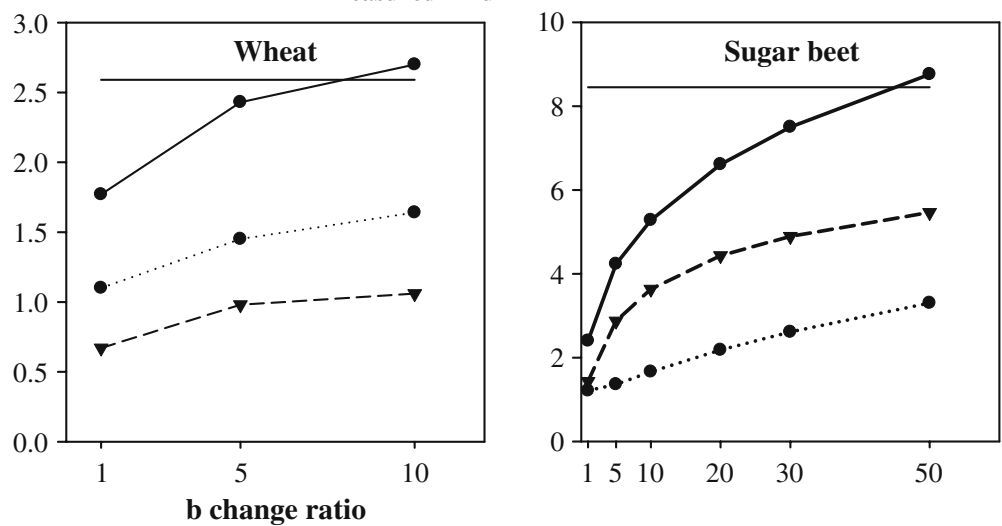

- Calculated influx of total root at different $I_{\text {max }}$ change ratio

-... Calculated influx of root cylinder at different $I_{\max }$ change ratio

$-\nabla-$ Calculated influx of root hairs at different $I_{\max }$ change ratio

Measured influx
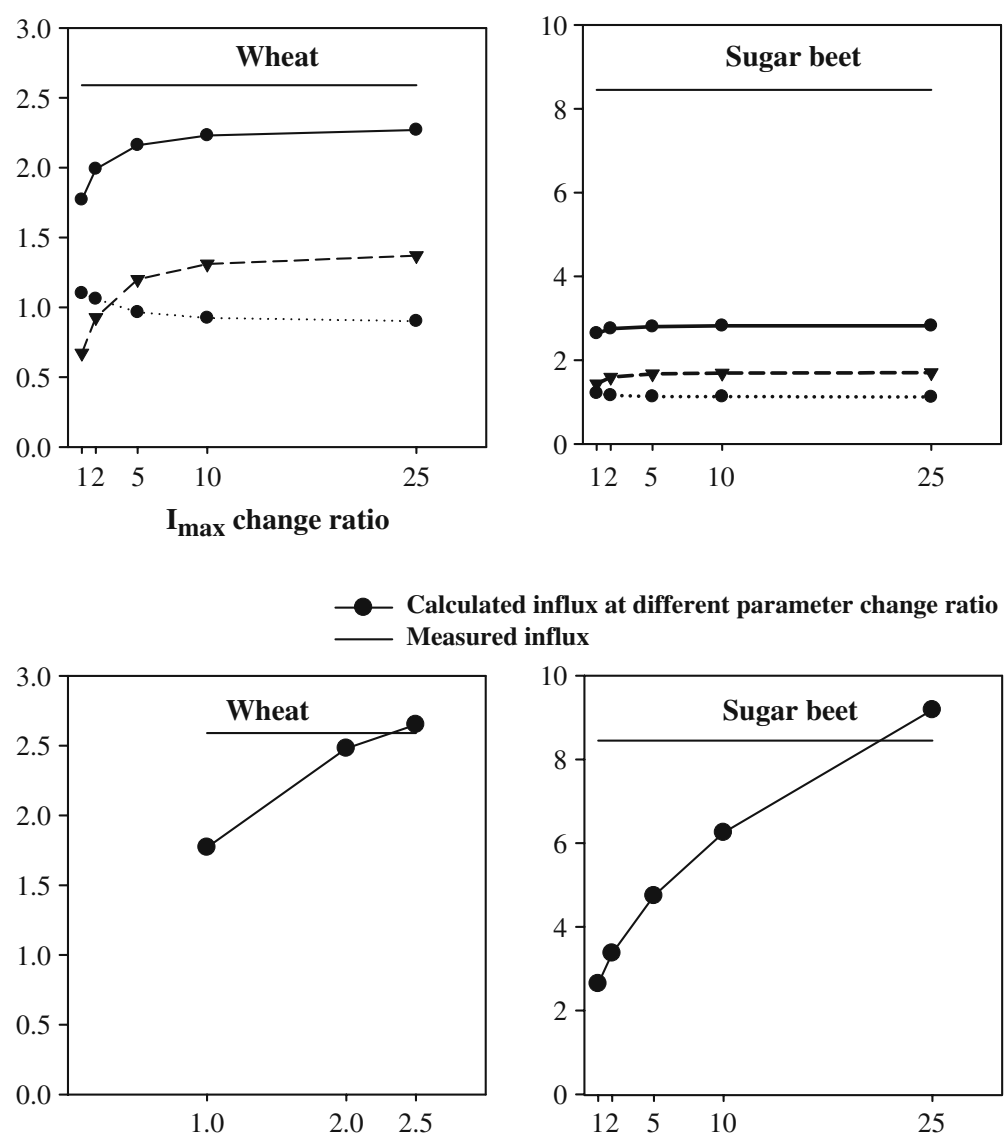

Parameter change ratio 


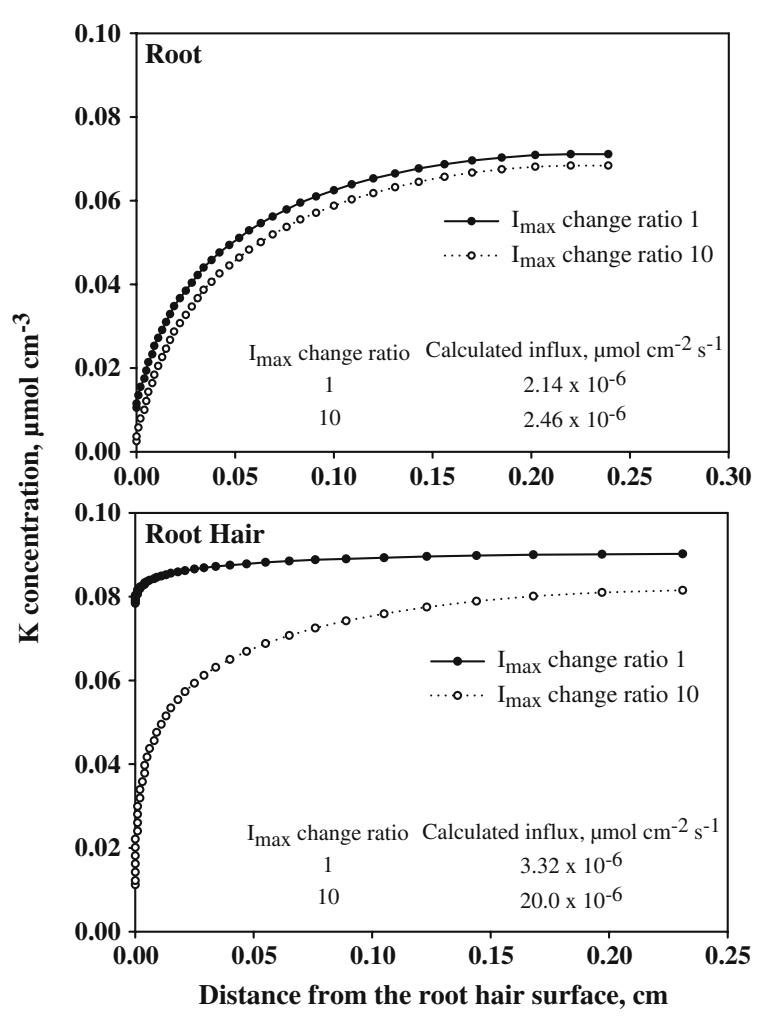

Fig. 7 Effect of changing $I_{\max }$ values on soil solution $\mathrm{K}$ concentrations at increasing distances from root and root hair surfaces of wheat. Changes in the calculated $\mathrm{K}$ influx are shown

resulted in predicted $\mathrm{K}$ influx being only $33 \%$ that of measured influx (Fig. 6b).

\section{Discussion}

In this study, we utilize model calculations and a sensitivity analysis to evaluate $\mathrm{K}$ uptake efficiency mechanisms of maize, wheat and sugar beet. In contrast to earlier studies with the NST 3.0 model (Sadana and Claassen 1999; Dessougi et al. 2002; Steingrobe et al. 2000), we also included the contribution of root hairs.

Sugar beet and wheat maintained higher shoot $\mathrm{K}$ concentrations as compared to maize (Fig. 2), and therefore, were thought to have a higher $\mathrm{K}$ uptake efficiency. Wheat acquired more $\mathrm{K}$ from a soil with low $\mathrm{K}$ supply because of its higher root length to shoot dry weight ratio (Table 1). Steingrobe and Claassen (2000) reported that in both soil and solution culture experiments, wheat and sugar beet were more
$\mathrm{K}$ efficient than potato, because wheat had a large root system and both species had an efficient uptake physiology. Root length to shoot dry weight ratio of sugar beet was half of that of maize under low $\mathrm{K}$ supply, but shoot $\mathrm{K}$ concentration was two-fold higher. Sugar beet could accumulate relatively more $\mathrm{K}$ in the shoot because of a 3- to 4-fold higher $\mathrm{K}$ influx (measured $\mathrm{K}$ influx) as compared to wheat and maize, respectively, which allowed the plants to compensate for the higher shoot demand per unit root length (Table 6). The higher $\mathrm{K}$ uptake efficiency of wheat was due to higher root length to shoot dry weight ratio and lower shoot demand as compared to sugar beet and maize (Table 1 and 2). Similar results were obtained by Sadana and Claassen (1999) and Dessougi et al. (2002) working with a K-fixing soil with low levels of plant-available $\mathrm{K}$. In comparison to the cereals, sugar beet maintained a high $\mathrm{K}$ concentration in the shoot even though shoot demand on the root was high (high relative growth rate and a small root system) because of high $\mathrm{K}$ influx. Based on the calculated concentration profile around the root surface, it was evident that the higher $\mathrm{K}$ influx in sugar beet was also due to the capacity of the sugar beet root to reduce solution $\mathrm{K}$ concentration at the root surface to a lower value as compared to wheat and maize, thereby creating a steeper concentration gradient and so increasing the diffusive transport of $\mathrm{K}$ to the root surface (Fig. 4).

The NST 3.0 nutrient uptake model slightly overpredicted $\mathrm{K}$ influx in maize and wheat, and slightly under-predicted influx in sugar beet, under high $\mathrm{K}$ supply conditions (Table 6). The close agreement between calculated and measured $\mathrm{K}$ influx indicated that the concept of diffusion, mass flow and $\mathrm{K}$ uptake physiology as the most important processes for $\mathrm{K}$ transport and uptake are appropriate and that the model input parameters were accurately measured. Under low $\mathrm{K}$ supply, however, the model prediction was $0.64,0.68$ and 0.31 of measured $\mathrm{K}$ influx for maize, wheat and sugar beet, respectively. To provide some insight into the possible reasons for such significant under-prediction, we conducted a sensitivity analysis with several key model parameters.

Initial soil solution concentration $\left(\mathrm{C}_{\mathrm{Li}}\right)$ is a parameter which can be measured relatively precisely - it is a reliable model input parameter. However, $\mathrm{C}_{\mathrm{Li}}$ is an average value for the whole soil, and can vary spatially. Therefore, sensitivity analysis for $\mathrm{C}_{\mathrm{Li}}$ was 
conducted. By increasing $\mathrm{C}_{\mathrm{Li}}$ by a factor of 1.6 for wheat and maize and 3.5 for sugar beet, $100 \%$ agreement for $\mathrm{K}$ influx was achieved under low $\mathrm{K}$ supply (Fig. 5). This suggests that increasing $\mathrm{C}_{\mathrm{Li}}$ by the plant may have been a mechanism to acquire $\mathrm{K}$ from soil. For instance, in most cases $\mathrm{Ca}$ accumulates at the root surface (Jungk and Claassen 1997) and this would increase the concentration of $\mathrm{K}$ in soil solution in the rhizosphere due to cation exchange processes (Schneider 1997). Sugar beet showed the highest water uptake rate (Table 4) and also showed the largest difference between measured and calculated $\mathrm{K}$ influx.

A further possibility to increase $\mathrm{K}$ solution concentration in the rhizosphere would have been through chemical mobilization, i. e. solubilization of $\mathrm{K}$ by plant root exudates.

Soil $\mathrm{K}$ buffer power, $\mathrm{b}$, cannot be determined precisely because the amount of plant available $\mathrm{K}$ on the soil solid phase can only be estimated. This was demonstrated in that the plants used not only exchangeable $\mathrm{K}$, but also non-exchangeable $\mathrm{K}$ (Fig. 3). Increasing b means increasing the "available" $\mathrm{K}$ at constant $\mathrm{C}_{\mathrm{Li}}$, in our case this would mean to include an increasing amount of non-exchangeable $\mathrm{K}$ in the calculations. Accurate model prediction for $\mathrm{K}$ influx was achieved by increasing the $b$ value by a factor of 10 in maize and wheat and by a factor of 50 in sugar beet (Fig. 6a).

The effect of an increasing $\mathrm{b}$ on the $\mathrm{K}$ influx may be attributed to less $\mathrm{K}$ depletion at the root surface or to a smaller extension of the depletion zone leading to inter-root competition only at higher root length density. The effect of $\mathrm{b}$ on less $\mathrm{K}$ depletion is relatively small as can be deduced from its effect on the influx of the root cylinder and as was shown by Claassen (1986); Claassen (1990) and Steingrobe et al. (2000). Increasing $b$ decreases the effective diffusion coefficient, $D_{e}\left(D_{e}=D_{L} \theta f / b\right)$ and consequently, the extension of the depletion zone. This would be more important for maize and wheat because separation among roots $\left(r_{1}\right)$ was relatively small and inter-root competition occurred (decrease in $\mathrm{C}_{\mathrm{L}}$ at $\mathrm{r}_{1}$, see Fig. 4). In a more highly buffered soil, there is less reduction of $C_{L}$ at $r_{1}$ and the concentration gradient towards the root increases, so that interroot competition is reduced (Steingrobe et al. 2000). Therefore, the $b$ value of a soil is of significance if inter-root competition occurs. Since $r_{1}$ for sugar beet is relatively large, we would expect a small effect of $b$ on $\mathrm{K}$ influx, but the contrary occurred. In this case, the effect of changing $\mathrm{b}$ mainly increased $\mathrm{K}$ uptake by root hairs (Fig. 6a), because $r_{1}$ h is very small (Table 5) and strong competition among root hairs occurred.

In a review of the $\mathrm{K}$ uptake efficiency of crops, Rengel and Damon (2008) argued that at limiting K supply, $\mathrm{K}$ uptake from soil is diffusion limited and therefore, increasing the uptake capacity of roots, i.e., $\mathrm{I}_{\max }$, would have limited effect on $\mathrm{K}$ uptake from soil. This likely is true for the root cylinder, but not for root hairs (as shown in Fig. 7). Figure 6b shows that increasing $\mathrm{I}_{\max }$ in maize and wheat by a factor of about 5 increased $\mathrm{K}$ influx, mainly as a result of $\mathrm{K}$ influx of root hairs. Further increases of $\mathrm{I}_{\max }$ had little effect on $\mathrm{K}$ influx, similar to the effect in sugar beet. It must be considered, however, that sugar beet had an $I_{\max } 5$ to 6 times higher than that of wheat or maize (Table 4). The lack of response to increased $I_{\max }$ by sugar beet or wheat and maize after a 5 -fold increase is because once the uptake capacity of the root hair reaches a given level, the entire soil volume occupied by root hairs is depleted of $\mathrm{K}$ due to the close proximity of the root hairs (small $r_{1} h$ ). However, if an increased $\mathrm{I}_{\max }$ is accompanied by an increased $\mathrm{b}$ (at constant $\mathrm{C}_{\mathrm{Li}}$, increasing $\mathrm{b}$ means an increase in relative amounts of solid-phase $\mathrm{K}$ ), it further increases $\mathrm{K}$ uptake (Fig. 6c).

To ensure an adequate supply of $\mathrm{K}$, plants have developed a number of highly specific mechanisms to take up $\mathrm{K}$ from the soil (Brüggemann et al. 1999; Ahn et al. 2004; Reintanz et al. 2002). Development of root hairs increases root surface area and consequently, the radius of the $\mathrm{K}$ depletion zone. Hogh-Jensen and Pedersen (2003) reported a positive correlation between the capacity to take up $\mathrm{K}$ from a K-deficient soil and root hair length for several diverse plant species. Although all species utilized the exchangeable $\mathrm{K}$ sources similarly, the crop species with the highest root surface area exploited the most sparingly soluble $\mathrm{K}$ as well. In our study, we observed from the sensitivity analysis that the increase in model prediction for $\mathrm{K}$ influx by increasing both $I_{\max }$ and $b$ was mostly due to the activity of root hairs.

Now, the question is whether the steeper concentration gradient created by the roots and/or root hairs is the result of more $\mathrm{K}$ desorbing to soil solution from the non-exchangeable fraction and thereby increasing 
$\mathrm{b}$, or are the sugar beet roots releasing organic compounds that solubilize $\mathrm{K}$ from soil minerals thereby increasing $\mathrm{K}$ concentration in soil solution close to the root surface? Springob and Richter (1998) reported that exudation of organic acids and/or protons is not necessary to make non-exchangeable $\mathrm{K}$ available to plant roots. They found that a decrease of $\mathrm{K}$ concentration in soil solution below $3.5 \mu \mathrm{M}$ initiated a release of interlayer $\mathrm{K}$ in a Luvisol. The minimum concentration at which uptake is possible $\left(\mathrm{C}_{\mathrm{Lmin}}\right)$ for most plant species is well below $3.5 \mu \mathrm{M}$. Hinsinger and Jaillard (1993) demonstrated that release of interlayer $\mathrm{K}$ in phlogopite occurred in the rhizosphere of ryegrass (Lolium perenne L.) when the $\mathrm{K}$ concentration in the rhizosphere solution decreased below a threshold of about $80 \mu M$ and that the release involved exchange of interlayer $\mathrm{K}$ by cations of high hydration energy, with a subsequent expansion of the interlayer space. The source and release processes of non-exchangeable $\mathrm{K}$ from the rhizosphere of maize were evaluated by Moritsuka et al. (2004). They reported that interlayer $\mathrm{K}$ in a 2:1 type phyllosilicate was the main source of non-exchangeable $K$ for maize, and that $\mathrm{K}$ was released through cation $\left(\mathrm{Ca}^{2+}\right.$, $\mathrm{Mg}^{2+}$, and $\mathrm{Na}^{+}$accumulated in the rhizosphere) exchange of the $\mathrm{K}$, rather than mineral dissolution by protons.

Sugar beet and wheat maintained higher shoot K concentrations, indicating higher $\mathrm{K}$ uptake efficiency. Wheat acquired more $\mathrm{K}$ because of a greater root length to shoot dry weight ratio. Sugar beet accumulated more shoot $\mathrm{K}$ as a result of a 3- to 4-fold higher $\mathrm{K}$ influx as compared to wheat and maize, respectively. Nutrient uptake model NST 3.0 closely predicted $\mathrm{K}$ influx when $250 \mathrm{mg} \mathrm{K} \mathrm{kg}{ }^{-1}$ were added to the soil, but under-predicted $\mathrm{K}$ influx under low $\mathrm{K}$ supply. Although we did not directly measure soil solution $\mathrm{K}$ concentrations in the rhizosphere, the model calculations lead us to speculate that besides $\mathrm{Ca}$ accumulation in the rhizosphere, chemical mobilization of $\mathrm{K}$ resulting in higher rhizosphere solution $\mathrm{K}$ concentrations may account for the underprediction of $\mathrm{K}$ influx under low $\mathrm{K}$ supply. On the other hand, the uptake kinetics of root hairs may be different from that of roots. Therefore, future studies should focus on direct measurements of $\mathrm{K}$ depletion around the root and root hair surfaces and better estimates of $\mathrm{K}$ uptake kinetics $\left(\mathrm{I}_{\max }, \mathrm{K}_{\mathrm{m}}\right.$, and $\left.\mathrm{C}_{\mathrm{Lmin}}\right)$ for root hairs.
Acknowledgements The financial assistance by the Ministry of Science and Culture, Lower Saxony, Germany and Indian Institute of Technology, Kharagpur, India is greatly acknowledged. We would also like to thank James Berkey, Agricultural Science Research Technician, USDA-ARS National Laboratory for Agriculture and the Environment, Ames, Iowa, USA for help in preparing experimental set up and doing soil and plant sample analyses.

Open Access This article is distributed under the terms of the Creative Commons Attribution Noncommercial License which permits any noncommercial use, distribution, and reproduction in any medium, provided the original author(s) and source are credited.

\section{References}

Adams F (1974) Soil solution. In: Carson EW (ed) The plant root and its environment. University of Virginia, Charlottesville, pp 441-481

Ahn SJ, Ryoung S, Daniel PS (2004) Expression of KT/KUP genes in arabidopsis and the role of root hairs in $\mathrm{K}^{[+]}$uptake. Plant Physiol 134:1135-1145. doi:10.1104/pp. 103.034660

Barber SA (1962) A diffusion and mass-flow concept of soil nutrient availability. Soil Sci 93:39-49

Barber SA (1995) Soil nutrient bioavailability — a mechanistic approach, 2nd edn. John Wiley, New York

Brown JR (1998) Recommended chemical soil test procedures for the North Central Region. North Central Regional Research Publication No. 221 (Revised). Missouri Agricultural Experiment Station, Colombia

Brüggemann L, Dietrich P, Becker D, Dreyer I, Palme K, Hedrich R (1999) Channel-mediated high-affinity $\mathrm{K}^{+}$ uptake into guard cells from arabidopsis. Proceedings of National Academy of Sciences United States of America 96:3298-3302

Claassen N (1986) Potassium availability: assessment of soil parameters by mathematical modeling. Transactions of the XIII. Congress of International Society of Soil Science, held at Hamburg 13-20 August 1986, Vol. III, 706-707

Claassen N (1990) Die Aufnahme von Nährstoffen aus dem Boden durch die höhere Pflanze als Ergebnis von Verfügbarkeit und Aneignungsvermögen. Habilitationsschrift, Universität Göttingen, Severin Verlag, Göttingen

Claassen N (1994) Nährstoffaufnahme höherer Pflanzen aus dem Boden: Ergebnis von Verfügbarkeit und Aneignungsvermögen. Zweite unveränderte Auflage. Severin Verlag, Göttingen

Claassen N, Steingrobe B (1999) Mechanistic simulation models for a better understanding of nutrient uptake from soil. In: Rengel Z (ed) Mineral nutrition of crops fundamental mechanisms and implications. Haworth, New York, pp 327-367

Claassen N, Syring KM, Jungk A (1986) Verification of a mathematical model by simulating potassium uptake from soil. Plant Soil 95:209-220. doi:10.1007/BF02375073

Dessougi HI (2001) Potassium efficiency of crop species as related to K Dynamics in the Rhizosphere Simulated by Mathematical modeling. Dissertation, Goettingen University 
Dessougi HI, Claassen N, Steingrobe B (2002) Potassium efficiency mechanisms of wheat, barley and sugar beet grown on a $\mathrm{K}$ fixing soil under controlled conditions. J Plant Nutr Soil Sci 165(6):732-737. doi:10.1002/jpln.200290011

Drew MC, Nye PH (1969) The supply of nutrient ions by diffusion to plant roots in soil. II. The effect of root hairs on the uptake of potassium by roots of rye grass. Plant Soil 31:407-424. doi:10.1007/BF01373813

Engels C, Marschner H (1993) Influence of the form of nitrogen supply on root uptake and translocation of cations in the xylem exudate of maize (Zea mays L.). J Exp Bot 44:16951701

Epstein E, Hagen CE (1952) A kinetic study of the absorption of alkali cations by barley roots. Plant Physiol 27:457-474

Ewing RP, Kaspar CT (1995) Accurate perimeter and length measurement using an edge chord algorithim. J Comput Assist Microsc 7(2):91-100

Hinsinger P, Jaillard B (1993) Root-induced release of interlayer potassium and vermiculitization of phlogopite as related to potassium depletion in the rhizosphere of ryegrass. Eur J Soil Sci 44:525-534. doi:10.1111/j.1365-2389.1993.tb00474

Hofbauer T (1990) Untersuchungen über den Influx von Kalium in die Wurzeln von Zukerrübe, Raps, Weizen und Mais und Ursachen der Unterschiede bei niedriger KVerfügbarkeit. Diplomarbeit, Universität Göttingen

Hogh-Jensen H, Pedersen MB (2003) Morphological plasticity by crop plants and their potassium use efficiency. J Plant Nutr 26:969-984. doi:10.1081/PLN-120020069

Jungk A (2001) Root hairs and the acquisition of plant nutrients from soil. J Plant Nutr Soil Sci 164:121-129. doi:10.1002/ 1522-2624(200104)164:2<121::AID-JPLN121>3.0.CO;2-6

Jungk A, Claassen N (1997) Ion diffusion in the soil-root system. Adv Agr 61:53-110

Kaselowsky J (1990) Wirkung von Lagerungsdichte und Wassergehalt des Bodens auf die Verfügbarkeit von Phosphat und Kalium sowie das Nährstoffaneignungsvermögen von Pflanzen. Dissertation, Universität Göttingen

Kaspar CT, Ewing RP (1997) ROOTEDGE: software for measuring root length from desktop scanner images. Agron J 89:932-940

Meyer D (1993) Effizienz von Kulturpflanzen bei der Nutzung des nichtaustauschbaren Kaliums von Böden. Dissertation, Universität Göttingen

Mills HA, Jones JB Jr (1996) Plant analysis handbook II. MicroMacro, Athens

Moritsuka N, Yanai J, Kosaki T (2004) Possible processes releasing nonexchangeable $\mathrm{K}$ from the rhizosphere of maize. Plant Soil 258:261-268. doi:10.1023/B:PLSO.0000016556.79278.7f

Nielsen NE (1972) A transport kinetic concept for ion uptake by plants, II: the concept and some theoretic considerations. Plant Soil 37:561-576. doi:10.1007/BF01348515
Parsons R (1959) Handbook of electrochemical constants. Academic, New York

Reintanz B, Szyroki A, Ivashikina N, Ache P, Godde M, Becker D, Palme K, Hedrich R (2002) AtKC1, a silent Arabidopsis potassium channel $\alpha$-subunit modulates root hair $\mathrm{K}^{+}$influx. Proceedings of National Academy of Sciences United States of America 99(6):4079-4084

Rengel Z, Damon PM (2008) Crops and genotypes differ in efficiency of potassium uptake and use. Physiol Plantarum 133(4):624-636. doi:10.1111/j.1399-3054.2008.01079

Rodriguez-Navarro A (2000) Potassium transport in fungi and plants. Biochimica et biophysica acta 1469(1):1-30. doi:10.1016/S0304-4157(99)00013-1

Sadana US, Claassen N (1999) Potassium efficiency and dynamics in the rhizosphere of wheat, maize and sugarbeet evaluated by a mechanistic model. J Plant Nutr 22(6):939-50

Schneider A (1997) Influence of soil solution Ca concentration on short-term K release and fixation of a loamy soil. Eur J Soil Sci 48:513-522. doi:10.1111/j.1365-2389.1997. tb00217.x

Smucker AJ, Burney SM, Srivastava A (1982) Quantitative separation of roots from compacted soil profiles by hydro pneumatic elutriation system. Agron J 74:500-503

Springob G, Richter J (1998) Measuring interlayer potassium release rates from soil minerals. II. A percolation procedure to study the influence of the variable 'solute $\mathrm{K}$ ' in the $<1-$ $10 \mu \mathrm{M}$ range. Z Pflanzenernähr. Bodenkunde 161:315-322

Steingrobe B, Claassen N (2000) Potassium dynamics in the rhizosphere and K efficiency of crops. J Plant Nutr Soil Sci 163:101-106

Steingrobe B, Claassen N, Syring KM (2000) The effect of the function type for describing the soil buffer power on calculated ion transport to roots and nutrient uptake from the soil. J Plant Nutr Soil Sci 163:459-465

Trehan SP, Claassen N (1998) External K requirement of young plants of potato, sugar beet and wheat in flowing culture resulting from different internal requirements and uptake efficiency. Potato Res 41:229-237. doi:10.1007/ BF02358193

Trehan SP, Sharma RC (2002) Potassium uptake efficiency of young plants of three potato cultivars as related to root and shoot parameters. Commun Soil Sci Plant Anal 33:18131823

Williams RF (1948) The effect of phosphorus supply on the rates of intake of phosphorus and nitrogen upon certain aspects of phosphorus metabolism in gramineous plants. Aust J Sci Res (B) Biol Sci 11:333-361

Zhang Z, Tian X, Duan L, Wang B, He Z, Li Z (2007) Differential responses of conventional and Bt-transgenic cotton to potassium deficiency. J Plant Nutr 30:659670 